\title{
PENGARUH MODEL BRAIN BASED LEARNING BERBANTUAN BRAIN GYM TERHADAP KEMAMPUAN BERPIKIR KRITIS DITINJAU DARI MOTIVASI BELAJAR FISIKA PESERTA DIDIK
}

\section{THE EFFECT OF BRAIN GYM ASSISTED BRAIN BASED LEARNING MODEL ON CRITICAL THINKING SKILLS REVIEW FROM STUDENTS' PHYSICS LEARNING MOTIVATION}

\author{
Kadek Essy Novalianti*, Susilawati, dan Jannatin 'Ardhuha \\ Program Studi Pendidikan Fisika FKIP, Universitas Mataram, Mataram, Indonesia \\ *Email: kadekessy64@gmail.com
}

Diterima: 10 Oktober 2019. Disetujui: 18 Oktober 2019. Dipublikasikan: 9 Januari 2021

\begin{abstract}
Abstrak: Penelitian ini bertujuan untuk mengetahui pengaruh model brain based learning berbantuan brain gym terhadap kemampuan berpikir kritis peserta didik, pengaruh motivasi belajar fisika terhadap kemampuan berpikir kritis peserta didik, serta interaksi antara model brain based learning berbantuan brain gym dan motivasi belajar fisika terhadap kemampuan berpikir kritis peserta didik. Jenis penelitian ini adalah kuasi eksperimen dengan rancangan faktorial 2x2. Populasinya seluruh peserta didik kelas X MIPA SMAN 4 Mataram tahun pelajaran 2018/2019 yang berjumlah 131 orang, yang masing-masing dipilih 25 peserta didik dengan tehnik purposive sampling, baik untuk kelas eksperimen dan kelas kontrol. Terdapat dua sampel yang diambil yaitu peserta didik kelas X MIPA 3 sebagai kelas eksperimen yang diberikan perlakuan model brain based learning berbantuan brain gym dan peserta didik kelas X MIPA 1 sebagai kelas kontrol yang diberikan perlakuan model pembelajaran konvensional. Data diambil menggunakan tes essay sebanyak 5 item soal untuk mengetahui kemampuan berpikir kritis dan angket untuk mengetahui motivasi belajar fisika. Uji hipotesis menggunakan anava dua jalan dengan taraf signifikan $(\alpha) 5 \%$. Berdasarkan hasil analisis dapat disimpulkan bahwa terdapat pengaruh model brain based learning berbantuan brain gym terhadap kemampuan berpikir kritis peserta didik $(\alpha=0.000)$; terdapat pengaruh motivasi belajar fisika terhadap kemampuan berpikir kritis peserta didik $(\alpha=0.000)$; serta tidak terdapat interaksi antara model brain based learning berbantuan brain gym dan motivasi belajar fisika terhadap kemampuan berpikir kritis peserta didik $(\alpha=0.818)$.
\end{abstract}

Kata Kunci: Model brain based learning, brain gym, kemampuan berpikir kritis, motivasi belajar fisika.

\begin{abstract}
This study aims to determine the effect of brain-based learning model assisted with brain gym on students' critical thinking skills; the influence of physics learning motivation on students' critical thinking skills; as well as interactions between brain gym assisted brain-based learning models and physics learning motivation on participants' critical thinking skills. This research is a quasi-experiment with a $2 \times 2$ factorial design. The population was all students of class X MIPA SMAN 4 Mataram in the academic year of 2018/2019, comprising 131 people, from which 25 students were chosen with a purposive sampling technique in either experiment and control class. The students of class X MIPA 3 served as the experimental class who were given a brain-based learning model assisted by a brain gym, whereas the students of class X MIPA 1 served as the control class who were given conventional learning model treatments. Data were taken using essay tests consisting of 5 item questions to determine the critical thinking ability and questionnaires to assess motivation to learn physics. Hypothesis testing uses two-way ANOVA with a significance level $(\alpha)$ of $5 \%$. Based on the data analysis, it can be concluded that there was an influence of the brain gym assisted brain-based learning model on the students' critical thinking skills $(\alpha=0.000)$; there was also an influence of physics learning motivation on students' critical thinking skills $(\alpha=$ 0.000 ); and, however, there was no interaction between brain gym assisted based learning model and physics learning motivation on students' critical thinking skills $(\alpha=0.818)$.
\end{abstract}

Keywords: Brain based learning, brain gym, critical thinking skills, learning motivation.

\section{PENDAHULUAN}

Perkembangan ilmu pengetahuan dan teknologi yang pesat merupakan ciri era globalisasi pada abad 21 ini. Keadaan seperti ini menjadikan individu mudah mengakses dan memperoleh informasi [1]. Kemajuan ilmu pengetahuan dan teknologi tentu tidak terlepas dari IPA. Fisika sebagai bagian dari ilmu IPA hakekatnya merupakan suatu produk ( $a$ body of knowledge), proses ( $a$ way of investigating), dan sikap (a way of thinking) [2]. Hakekat fisika yang demikian menyebabkan penting untuk mengembangkan kemampuan berpikir kritis peserta didik di dalam pembelajaran abad 21 ini.

Menurut Fatmawati et al [3] tingkat kemampuan berpikir peserta didik terbagi menjadi berpikir tingkat dasar dan berpikir tingkat tinggi, di mana berpikir tingkat tinggi (higher order thinking) akan membuat peserta didik menginterpretasikan, 
menganalisa, atau bahkan mampu memanipulasi suatu informasi, sedangkan kemampuan berpikir tingkat dasar (lower order thinking) hanya menggunakan kemampuan yang terbatas pada hal-hal rutin dan bersifat mekanis. Pentingnya pengembangan kemampuan berpikir kritis sebagai bagian dari kemampuan berpikir tingkat tinggi, diungkapkan oleh The Secretary's Commission on Achieving Necessary Skills pada tahun 1990 yang menyatakan bahwa kompetensi berpikir kritis, membuat keputusan, problem solving, dan bernalar sebagai sesuatu yang penting dalam prestasi kerja [4]. Menurut Ennis [5] berpikir kritis merupakan pemikiran beralasan dan reflektif yang berfokus pada penentuan apa yang dipercayai dan dilakukan. Yeritia et al [6] menyatakan berpikir kritis adalah sebuah proses mental, tujuannya untuk membuat keputusan yang logis tentang apa yang harus diyakini dan apa yang harus dilakukan.

Pengembangan kemampuan berpikir kritis dalam pembelajaran dapat dipengaruhi oleh motivasi yang dimiliki peserta didik, menurut Sardiman [7] pembelajaran akan optimal jika ada motivasi yang tepat. Motivasi merupakan suatu variabel yang digunakan untuk membangkitkan, mengelola, mempertahankan dan menyalurkan tingkah laku menuju suatu tujuan [8]. Motivasi peserta didik yang rendah dapat berdampak pada proses dan hasil belajar yang tidak meningkat dengan baik atau bahkan dapat menurun [9]. Salah satu faktor penyebab rendahnya motivasi belajar fisika peserta didik yaitu proses pembelajaran yang lebih bersifat konvensional (teacher-centered) [10].

Berdasarkan hasil observasi di SMAN 4 Mataram, guru fisika cenderung menggunakan pembelajaran konvensional di mana guru menjadi satu-satunya sumber pengetahuan. Kecenderungan guru dalam menempatkan diri sebagai sumber utama pengetahuan sering dilatarbelakangi oleh target mengejar materi pelajaran yang telah ditetapkan kurikulum sehingga fokus guru dalam mengukur keberhasilan peserta didik terbatas pada ketuntasan hasil belajarnya. Sudarmini et al [11] mengatakan kenyataan di lapangan yang menunjukkan masih banyaknya guru yang menggunakan metode ceramah menyebabkan peserta didik kurang diberikan kesempatan untuk terlibat aktif selama proses pembelajaran, hal ini mengakibatkan tidak terlatihnya kemampuan berpikir tingkat tinggi peserta didik salah satunya kemampuan berpikir kritis.

Berdasarkan hasil wawancara dengan salah satu guru fisika di SMAN 4 Mataram, kemampuan berpikir kritis peserta didik masih berada dalam level rendah karena peserta didik hanya mengandalkan guru untuk memperoleh pengetahuan. Temuan di lapangan juga memperlihatkan, peserta didik cenderung menganggap pelajaran fisika bersifat hafalan rumus sehingga pelajaran fisika sering disamakan dengan matematika. Padahal, dibutuhkan kemampuan berpikir dalam tingkatan yang lebih tinggi untuk mampu menganalisis berbagai fenomena dalam fisika dan mengaitkannya dengan persamaan yang akan digunakan untuk mencari jawaban atas persoalan tersebut. Kecenderungan ini mengakibatkan hanya beberapa peserta didik yang mampu menjawab soal-soal yang membutuhkan kemampuan berpikir kritis. Rendahnya kemampuan matematis dasar, motivasi belajar, kurangnya penggunaan variasi model pembelajaran dan pengaplikasian soal-soal yang melatih kemampuan berpikir kritis juga menjadi penyebab kemampuan berpikir kritis peserta didik belum dikembangkan.

Beranjak dari permasalahan tersebut, perlu adanya upaya dan inovasi pembelajaran yang membantu peserta didik untuk membangun motivasi belajarnya sehingga akan lebih mudah untuk mengembangkan kemampuan berpikir kritisnya. Salah satu upaya yang dapat dilakukan adalah dengan menerapkan model brain based learning. Menurut Mufidah [12] model brain based learning memiliki tiga strategi penting dalam penerapannya yaitu menciptakan lingkungan belajar yang menantang kemampuan berpikir, menciptakan kondisi lingkungan belajar yang menyenangkan dan menciptakan situasi pembelajaran aktif dan bermakna. Pembelajaran menggunakan model ini menawarkan konsep untuk menciptakan pembelajaran yang berorientasi pada keseimbangan penggunanaan potensi otak kiri dan otak kanan [13].

Menurut Jensen [14] model brain based learning terdiri dari 7 tahap yang meliputi prapemaparan, persiapan, inisiasi dan akuisisi, elaborasi, inkubasi dan pengaturan memori, verifikasi atau pengecekan, serta selebrasi dan integrasi. Tahap prapemaparan adalah tahap di mana guru memberikan gambaran mengenai pembelajaran yang akan diberikan. Tahap persiapan adalah tahap di mana guru membangun keingintahuan peserta didik. Tahap inisiasi dan akuisisi adalah tahap di mana guru menyampaikan materi pembelajaran. Tahap elaborasi adalah tahap di mana guru menyediakan kesempatan kepada peserta didik untuk menyortir, menyelidiki, menganalisis, menguji dan memperdalam pelajaran. Guru dapat menyelenggarakan sesi tanya jawab pada tahap ini. Tahap inkubasi dan pengaturan memori adalah tahap istirahat di mana guru dapat meminta peserta didik untuk melakukan peregangan, permainan, latihan relaksasi dan menyediakan area pendengaran musik. Tahap verifikasi atau pengecekan adalah tahap di mana guru mengecek pemahaman peserta didik, guru dapat meminta peserta didik untuk menulis jurnal, laporan atau memberikan kuis. Tahap perayaan dan integrasi adalah tahap akhir di mana guru menanamkan arti penting dan kecintaan belajar kepada peserta didik. 
Jensen [14] menyatakan efek sensori dan fisiologi memiliki peranan penting dalam mengoptimalkan proses pembelajaran. Adapun efek sensori dan fisiologi tersebut dijabarkan sebagai berikut:

1. Efek Sensori

Efek sensori yang dapat membantu mengoptimalkan proses pembelajaran meliputi;

a. Media Visual

Otak menyerap rangsangan informasi visual antara $80 \%-90 \%$. Media visual yang dapat digunakan seperti objek-objek konkret, fotografi, grafik, bagan, slide, video, warna, poster dan peta pikiran.

b. Akustik (Musik)

Weinberger seorang neuroscientist pada University of California, menunjukkan bahwa otak dikhususkan untuk membangun blok musik. Ketika informasi diberi imbuhan musik yang tepat, kemungkinan besar otak akan mengkodefikasinya dalam memori jangka panjang.

\section{Efek Fisiologi}

Efek fisiologi yang dapat membantu mengoptimalkan proses pembelajaran meliputi:

a. Relaksasi (Waktu Istirahat)

Relaksasi dalam brain based learning merupakan waktu istirahat guna mendapatkan kinerja terbaik otak, dapat berupa memberikan kesempatan untuk sesekali minum atau jalan keliling kepada peserta didik.

b. Latihan Fisik

Latihan fisik dapat dilakukan dengan hal-hal sederhana seperti peregangan singkat, latihan nafas lebih perlahan, keluar untuk melakukan suatu proyek dan mengerjakan teka-teki.

Terkait dengan latihan fisik, penelitian ini memadukan model brain based learning dengan brain gym (senam otak). Menurut Diana et al [15] brain gym adalah latihan yang dirancang untuk membantu fungsi otak yang lebih baik selama proses pembelajaran, yang didasarkan pada gagasan bahwa latihan fisik sederhana membantu aliran darah ke otak dan membantu meningkatkan proses belajar. Menurut Purwanto et al [16] gerakan brain gym memiliki beberapa keuntungan yaitu memungkinkan belajar dan bekerja tanpa stress, tidak memerlukan tempat yang khusus dan dapat dilakukan dalam waktu singkat, dapat dipakai dalam semua situasi belajar/bekerja dalam kehidupan sehari-hari, meningkatkan kepercayaan diri serta sangat efektif dalam penanganan seorang yang mengalami hambatan dan stres belajar.

Ada enam gerakan brain gym yang digunakan dalam penelitian ini, meliputi gerakan silang (cross crawl), menguap berenergi (energy yawn), burung hantu (the owl), mengaktifkan tangan (arm activation), gajah (the elephant), dan titik positif (positive points). Masing-masing pertemuan menggunakan dua gerakan yang diterapkan pada kegiatan pendahuluan (tahap prapemaparan) atau kegiatan inti (tahap inkubasi dan pengaturan memori). Penerapan gerakan brain gym dalam pembelajaran perlu diperhatikan agar pelaksanaan gerakan dapat optimal.

Hasil penelitian Nahdi [17] menyatakan terjadi peningkatan kemampuan berpikir kritis yang lebih tinggi pada peserta didik yang diajarkan dengan model brain based learning dibanding dengan peserta didik yang diajarkan dengan model pembelajaran konvensional karena banyak sekali aktivitas-aktivitas belajar pada model ini yang dapat menunjang kemampuan berpikir kritis peserta didik. Penelitian yang dilakukan Sariana et al [18] menyatakan terdapat pengaruh penerapan brain gym terhadap minat belajar peserta didik pada mata pelajaran fisika. Keselarasan model brain based learning dengan brain gym membuat peneliti merasa perlu melakukan penelitian lebih lanjut dengan harapan mampu menyelesaikan permasalahan di atas dalam membantu meningkatkan motivasi belajar fisika peserta didik sehingga kemampuan berpikir kritisnya dapat dikembangkan dalam proses pembelajaran.

\section{METODE PENELITIAN}

Jenis penelitian ini adalah quasi experiment dengan desain penelitian pretest-posttest control group design. Rancangan penelitian yang digunakan adalah faktorial 2x 2 yang dapat dilihat pada Tabel 1 .

Tabel 1. Rancangan Faktorial $2 \times 2$

\begin{tabular}{lcc}
\hline & \multicolumn{2}{c}{ Model Pembelajaran $(\mathrm{X})$} \\
\cline { 2 - 3 } Motivasi & \multicolumn{2}{c}{ Model } \\
Belajar $(\mathrm{Y})$ & $\begin{array}{c}\text { Model BBL } \\
\left(\mathrm{X}_{1}\right)\end{array}$ & $\begin{array}{c}\text { Konvensional } \\
\left(\mathrm{X}_{2}\right)\end{array}$ \\
\hline Tinggi $\left(\mathrm{Y}_{1}\right)$ & $\mathrm{X}_{1} \mathrm{Y}_{1}$ & $\mathrm{X}_{2} \mathrm{Y}_{1}$ \\
Rendah $\left(\mathrm{Y}_{2}\right)$ & $\mathrm{X}_{1} \mathrm{Y}_{2}$ & $\mathrm{X}_{2} \mathrm{Y}_{2}$ \\
\hline
\end{tabular}

Y merupakan motivasi belajar yang dikategorikan menjadi $Y_{1}$ yaitu motivasi belajar tinggi dan $Y_{2}$ yaitu motivasi belajar rendah, sedangkan $\mathrm{X}$ merupakan model pembelajaran yang diterapkan meliputi $\mathrm{X}_{1}$ model brain based learning dan $X_{2}$ model pembelajaran konvensional. $X_{1} Y_{1}$, $\mathrm{X}_{1} \mathrm{Y}_{2}, \mathrm{X}_{2} \mathrm{Y}_{1}$ dan $\mathrm{X}_{2} \mathrm{Y}_{2}$ adalah kombinasi antara motivasi belajar dengan model pembelajaran.

Variabel bebas dalam penelitian ini yakni model brain based learning berbantuan brain gym, variabel terikat yakni kemampuan berpikir kritis, variabel moderator yakni motivasi belajar fisika dan variabel kontrol yakni alokasi waktu, materi ajar, instrumen dan guru yang mengajar. Populasi dalam penelitian ini adalah seluruh peserta didik kelas $\mathrm{X}$ MIPA di SMAN 4 Mataram tahun pelajaran 2018/2019. Sampel penelitian diambil menggunakan tenik purposive sampling sehingga terpilih kelas $\mathrm{X}$ 
MIPA 3 sebagai kelas eksperimen dan X MIPA 1 sebagai kelas kontrol dengan jumlah peserta didik sama yaitu 25 orang.

Model brain based learning berbantuan brain gym diterapkan pada peserta didik di kelas eksperimen dan model pembelajaran konvensional diterapkan pada peserta didik di kelas kontrol. Kedua kelas diberikan perlakuan selama tiga kali pertemuan dengan materi momentum dan impuls. Motivasi belajar fisika peserta didik diukur menggunakan instrumen angket motivasi belajar yang terdiri atas 40 butir pernyataan yang telah diuji validitas.

Angket mengunakan indikator motivasi belajar yang dijabarkan oleh Uno dalam Hendrayana et al [19] diantaranya adanya hasrat dan keinginan berhasil, adanya dorongan dan kebutuhan dalam belajar, adanya harapan dan cita-cita masa depan, adanya penghargaan dalam belajar, adanya kegiatan yang menarik dalam belajar dan adanya lingkungan belajar yang kondusif. Pengelompokkan kriteria motivasi belajar peserta didik didasarkan pada ratarata nilai angket motivasi belajar pada setiap kelas. Peserta didik yang memiliki nilai motivasi belajar minimal sama dengan nilai rata-rata motivasi belajar di kelasnya dikategorikan memiliki motivasi belajar tinggi dan sisanya masuk kategori motivasi belajar rendah [20].

Kemampuan berpikir kritis diukur menggunakan 5 butir soal tes uraian yang telah diuji validitas, realibilitas, tingkat kesukaran, dan daya beda. Masing-masing soal mewakili indikator kemampuan berpikir kritis yang dijabarkan oleh Facione [21] diantaranya interpretasi, analisis, inferensi, eksplanasi, dan evaluasi. Data hasil kemampuan berpikir kritis diuji prasyarat, berupa uji homogenitas dan uji normalitas. Kemudian nilai kemampuan berpikir kritis (NKBK) peserta didik dikategorikan berdasarkan kriteria kemampuan berpikir kritis seperti Tabel 2 .

Tujuan dari penelitian ini untuk mengetahui pengaruh model brain based learning berbantuan brain gym terhadap kemampuan berpikir kritis peserta didik, pengaruh motivasi belajar fisika terhadap kemampuan berpikir kritis peserta didik dan interaksi antara model brain based learning berbantuan brain gym dengan motivasi belajar terhadap kemampuan berpikir kritis peserta didik. Uji hipotesis menggunakan analisis varians dua jalan (anava) berbantuan SPSS 16 dengan taraf signifikan $5 \%$.

Tabel 2. Kriteria Kemampuan Berpikir Kritis

\begin{tabular}{cc}
\hline Rentang nilai & Kategori \\
\hline $0 \leq N K B K \leq 60$ & Rendah \\
$60<N K B K \leq 75$ & Sedang \\
$75<N K B K \leq 100$ & Tinggi \\
\hline
\end{tabular}

\section{HASIL DAN PEMBAHASAN}

Penelitian dimulai dengan memberikan angket motivasi belajar fisika kepada masing-masing peserta didik di kedua kelas. Data hasil angket motivasi belajar fisika lalu dikategorikan menjadi motivasi belajar tinggi dan motivasi belajar rendah. Berdasarkan angket yang telah dibagikan diperoleh skor nilai rata-rata motivasi belajar peserta didik kelas eksperimen sebesar 75,38 sedangkan kelas kontrol sebesar 75,57. Jumlah peserta didik kategori motivasi belajar tinggi pada kelas eksperimen sebanyak 13 orang, sedangkan pada kelas kontrol sebanyak 17 orang. Jumlah peserta didik kategori motivasi belajar rendah pada kelas eksperimen sebanyak 12 orang, sedangkan pada kelas kontrol sebanyak 8 orang.

Sebelum diberi perlakuan, peserta didik pada kedua kelas diberi tes awal (pretest). Kemudian setelah diberi perlakuan peserta didik pada kedua kelas diberi tes akhir (posttets) untuk mengetahui kemampuan berpikir kritis peserta didik pada masing-masing kelas. Data hasil tes awal dan tes akhir kemampuan berpikir kritis peserta didik pada kedua kelas ditunjukkan pada Tabel 3.

Tabel 3. Hasil Tes Awal dan Tes Akhir Kemampuan Berpikir Kritis Peserta Didik pada Kedua Kelas

\begin{tabular}{lcccc}
\hline \multirow{2}{*}{ Data } & \multicolumn{2}{c}{ Tes Awal } & \multicolumn{2}{c}{ Tes Akhir } \\
\cline { 2 - 5 } & Kelas & Kelas & Kelas & Kelas \\
& Eksperimen & Kontrol & Eksperimen & Kontrol \\
\hline Jumlah Peserta Didik & 25 & 25 & 25 & 25 \\
Nilai Tertinggi & 50 & 55 & 95 & 85 \\
Nilai Terendah & 15 & 15 & 25 & 20 \\
Rata-rata & 30 & 33 & 61.6 & 52.4 \\
Kategori Kemampuan Berpikir Kritis & Rendah & Rendah & Sedang & Rendah \\
\hline
\end{tabular}

Berdasarkan tabel di atas, nilai rata-rata tes akhir kemampuan berpikir kritis peserta didik pada kedua kelas mengalami peningkatan. Kelas eksperimen memiliki nilai rata-rata tes akhir sebesar
61.6 tergolong ke dalam kategori sedang. Kelas kontrol memiliki rata-rata nilai tes akhir sebesar 52.4 tergolong ke dalam kategori rendah. Peningkatan nilai rata-rata kemampuan berpikir kritis pada kelas 
eksperimen yang diterapkan model brain based learning berbantuan brain gym lebih tinggi daripada kelas yang diterapkan model pembelajaran konvensional. Data motivasi belajar fisika dan kemampuan berpikir kritis peserta didik pada kedua kelas kemudian dianalisis menggunakan uji statistik anava dua jalan berbantuan SPSS 16. Hasil uji statistik ditunjukkan pada Tabel 4.

Berdasarkan analisis statistik anava dua jalan didapatkan nilai signifikansi untuk hipotesis pertama sebesar 0.000 lebih kecil dari 0.050 sehingga model brain based learning berbantuan brain gym berpengaruh terhadap kemampuan berpikir kritis peserta didik. Pembelajaran dengan model brain based learning berbantuan brain gym yang berlangsung di kelas eksperimen menunjukkan adanya latihan yang mampu mengembangkan kemampuan berpikir kritis peserta didik dengan mengedepankan keseimbangan kedua bagian otak peserta didik saat proses pembelajaran. Hal ini karena peneliti menerapkan tiga strategi model brain based learning dalam proses pembelajaran yang meliputi: pertama, peneliti memberikan soal-soal diskusi yang memfasilitasi kemampuan berpikir peserta didik dengan mengemasnya semenarik mungkin disertai gambar ilustrasi pada setiap butir soal. Kedua, menerapan gerakan brain gym, melakukan pembelajaran dengan diiringi musik pada waktu pemberian jeda istirahat, dan melakukan kegiatan diskusi kelompok agar membuat peserta didik merasa termotivasi untuk belajar. Ketiga, menciptakan situasi pembelajaran aktif dengan memberikan sesi tanya jawab dan presentasi hasil diskusi.

Tabel 4. Hasil Uji Anava Dua Jalan dengan SPSS 16

\begin{tabular}{llllll}
\hline Source & $\begin{array}{l}\text { Type III Sum of } \\
\text { Squares }\end{array}$ & df & $\begin{array}{l}\text { Mean } \\
\text { Square }\end{array}$ & F & Sig \\
\hline Corrected Model & 9207.805 & 3 & 3069.268 & 24.375 & .000 \\
Intercept & 137743.764 & 1 & 137743.764 & $1.094 \mathrm{E} 3$ & .000 \\
Model & 2045.134 & 1 & 2045.134 & 16.242 & .000 \\
Motivasi & 8072.751 & 1 & 8072.751 & 64.112 & .000 \\
Model*Motivasi & 6.778 & 1 & 6.778 & .054 & .818 \\
Error & 5792.195 & 46 & 125.917 & & \\
Total & 177450.000 & 50 & & & \\
Corrected Total & 15000.000 & 49 & & & \\
\hline
\end{tabular}

Perkembangan kemampuan berpikir kritis peserta didik pada kelas eksperimen dapat dilihat dari jawaban lembar diskusi peserta didik (LDPD) yang diberikan setiap pertemuan. Jawaban lembar diskusi peserta didik di kelas eksperimen memaparkan penjelasan yang lebih mendalam dan sistematis dibandingkan, jawaban lembar diskusi peserta didik di kelas kontrol yang hanya sebatas teori dan rumus jadi tanpa adanya penjelasan lebih lanjut.

Penerapan model brain based learning pada kelas eksperimen ini dipadukan dengan melakukan gerakan brain gym pada kegiatan pendahuluan atau kegiatan inti pembelajaran. Penerapan gerakan brain gym pada kegiatan pendahuluan dipilih peneliti dengan tujuan menciptakan suasana awal pembelajaran yang menyenangkan untuk memotivasi peserta didik dan merangsang kesiapan seluruh panca indera agar mampu bersinergi saat proses pembelajaran. Penerapan brain gym pada kegiatan inti diterapkan disela-sela kegiatan pembelajaran pada saat peserta didik telah selesai mendiskusikan LDPD tujuannya untuk menciptakan keseimbangan fungsi otak yang di mana ketika kegiatan diskusi bagian otak yang lebih dominan berfungsi adalah otak kiri sehingga penerapan brain gym diharapkan dapat merangsang fungsi kerja otak kanan.
Berdasarkan pengamatan peneliti, gerakan brain gym pada kegiatan pendahuluan (tahap prapemaparan) terlihat lebih optimal dilakukan oleh peserta didik dibanding dengan gerakan brain gym pada kegiatan inti (tahap inkubasi atau memasukkan memori), hal ini karena pada kegiatan pendahuluan kondisi peserta didik masih dalam keadaan yang lebih bugar. Gerakan brain gym yang dilaksanakan pada setiap pertemuan di kelas eksperimen mendapatkan respon yang sangat baik dari sebagian besar peserta didik. Terutama ketika melakukan gerakan menguap berenergi (energy yawn) di mana gerakan tersebut memperagakan gaya orang yang sedang menguap keras sembari memijat otot di sekitar persendian rahang, peserta didik merasa tertarik dan sangat ceria ketika melakukannya. Gerakan brain gym ini mampu mengurangi rasa canggung yang dimiliki peserta didik selama kegiatan belajar mengajar, membuat peserta didik menjadi aktif dan tidak malu untuk bertanya jika terdapat hal-hal yang kurang dipahami.

Hasil penelitian terkait model brain based learning dan brain gym dilakukan sebelumnya oleh Khuluqiyah \& Arief [22] menggunakan enam gerakan brain gym meliputi gerakan delapan angka tidur, silang, sakelar otak, kait rileks, mengaktifkan tangan, dan pasang telinga, bertujuan untuk 
mengetahui hasil belajar peserta didik kelas VIII pada materi alat-alat optik. Hasil penelitian ini menunjukkan peserta didik yang menerapkan gerakan brain gym memiliki hasil belajar yang lebih baik daripada hasil belajar peserta didik yang tidak menerapkan. Penelitian yang dilakukan oleh Herliandry et al [23] menyatakan terjadi peningkatan kemampuan berpikir kritis yang signifikan pada kelas yang diterapkan model brain based learning dibanding kelas yang diterapkan model pembelajaran ekspositor.

Berdasarkan analisis statistik anava dua jalan didapatkan nilai signifikansi untuk hipotesis kedua sebesar 0.000; sehingga ada pengaruh motivasi belajar terhadap kemampuan berpikir kritis peserta didik. Peserta didik pada kelas eksperimen memiliki nilai rata-rata kemampuan berpikir kritis untuk kategori motivasi belajar tinggi sebesar 74.62 dengan jumlah peserta didik 13 orang, sedangkan nilai ratarata kemampuan berpikir kritis peserta didik untuk kategori motivasi belajar rendah sebesar 47.5 dengan jumlah peserta didik 12 orang. Peserta didik pada kelas kontrol memiliki nilai rata-rata kemampuan berpikir kritis untuk kategori motivasi belajar tinggi sebesar 60.59 dengan jumlah peserta didik 17 orang, sedangkan nilai rata-rata kemampuan berpikir kritis peserta didik untuk kategori motivasi belajar rendah sebesar 35 dengan jumlah peserta didik 8 orang.

Hal ini memperlihatkan bahwa motivasi belajar peserta didik berpengaruh terhadap kemampuan berpikir kritis [26-28]. Peserta didik yang tergolong kategori motivasi belajar tinggi baik pada kelas eksperimen maupun kelas kontrol, cenderung terlihat lebih serius dalam menyimak penjelasan dan lebih aktif bertanya jika terdapat halhal yang belum dipahami saat proses pembelajaran. Tentu hal ini berpengaruh pada perolehan hasil tes akhir kemampuan berpikir kritis, peserta didik dengan kategori motivasi belajar tinggi mendapatkan nilai yang lebih baik dibanding peserta didik dengan kategori motivasi belajar rendah. Motivasi belajar memiliki hubungan yang sangat kuat dengan kemampuan berpikir kritis peserta didik [24,29]. Namun model pembelajaran yang digunakan dan motivasi belajar tidak memiliki interaksi secara bersamaan dalam meningkatkan kemampuan berpikir kritis peserta didik.

Nilai signifikansi untuk hipotesis ketiga sebesar 0.818 lebih besar dari 0.050 sehingga tidak ada interaksi antara model brain based learning berbantuan brain gym dan motivasi belajar terhadap kemampuan berpikir kritis peserta didik. Peserta didik kelompok motivasi belajar tinggi mempunyai nilai rata-rata kemampuan berpikir kritis yang lebih tinggi dibandingkan peserta didik kelompok motivasi belajar rendah. Peneliti menduga hal ini terjadi karena ketika kegiatan diskusi, peserta didik dengan kategori motivasi belajar tinggi terlihat cenderung hanya berdiskusi dengan peserta didik kategori motivasi tinggi juga di dalam kelompok yang sama, sehingga peserta didik yang berkategori motivasi belajar rendah kurang dilibatkan dan menerima jadi hasil diskusi kelompoknya. Sehingga, transfer ilmu dari peserta didik dengan kategori motivasi belajar tinggi kepada peserta didik dengan kategori motivasi belajar rendah menjadi kurang maksimal.

Hasil penelitian ini sejalan dengan hasil penelitian yang diperoleh Medyasari et al [25] yang menyatakan tidak ada interaksi antara model pembelajaran dan motivasi belajar terhadap prestasi belajar peserta didik dikarenakan rerata prestasi belajar peserta didik di kelas eksperimen selalu lebih tinggi dibandingkan dengan prestasi belajar pada kelas kontrol baik pada peserta didik dengan tingkat motivasi tinggi, sedang atau rendah. Menurutnya hal ini dikarenakan peserta didik kurang disiplin dalam mengikuti kegiatan pembelajaran, belum terbiasa dengan model pembelajaran yang digunakan, serta adanya variabel bebas yang tidak digunakan dalam penelitian.

\section{KESIMPULAN}

Penerapan model brain based learning berbantuan brain gym berpengaruh terhadap kemampuan berpikir kritis peserta didik, di mana motivasi belajar berpengaruh terhadap kemampuan berpikir kritis peserta didik. Akan tetapi, tidak terdapat interaksi antara model brain based learning berbantuan brain gym dan motivasi belajar terhadap kemampuan berpikir kritis peserta didik.

\section{DAFTAR PUSTAKA}

[1] Hidayanti, D., As'ari, A. R., \& Daniel, T. (2016). Analisis Kemampuan Berpikir Kritis Siswa SMP Kelas IX Pada Materi Kesebangunan. Konferensi Nasional Penelitian Matematika dan Pembelajarannya (KNPMP I): 2502-6526.

[2] Handriani, L.S., Harjono, A., \& Doyan A. (2015). Pengaruh Model Pembelajaran Inkuiri Terstruktur Dengan Pendekatan Saintifik Terhadap Kemampuan Berpikir Kritis Dan Hasil Belajar Fisika Siswa. Jurnal Pendidikan Fisika dan Teknologi. 1(3): 2407-6902.

[3] Fatmawati, H., Mardiyana., \& Triyanto. (2014). Analisis Berpikir Kritis Siswa Dalam Pemecahan Masalah Matematika Berdasarkan Polya Pada Pokok Bahasan Persamaan Kuadrat (Penelitian Pada Siswa Kelas X SMK Muhammadiyah 1 Sragen Tahun Pelajaran 2013/2014). Jurnal Elektronik Pembelajaran Matematika. 2(9).

[4] Kurniasih, A.W. (2010). Penjenjangan Kemampuan Berpikir Kritis Mahasiswa Prodi Pendidikan Matematika FMIPA UNNES dalam Menyelesaikan Masalah Matematika. 
Seminar Nasional Matematika dan Pendidikan Matematika.

[5] Ennis, R. H. (2011). The nature of critical thinking: An outline of critical thinking dispositions and abilities. University of Illinois, 2(4).

[6] Yeritia, S., Wahyudi., \& Rahayu, S. (2017). Pengaruh Model Pembelajaran Inkuiri Terbimbing Terhadap Penguasaan Konsep dan Kemampuan Berpikir Kritis Fisika Peserta Didik Kelas X Sman 1 Kuripan Tahun Ajaran 2017/2018. Jurrnal Pendidikan Fisika dan Teknologi. 3(2): 2407-6902

[7] Sardiman, A.M. (2014). Interaksi dan Motivasi Belajar Mengajar. Jakarta: Rajawali Press.

[8] Muthmainnah, M., Rokhmat J., \& 'Ardhuha, J. (2017). Pengaruh Penerapan Metode Pembelajaran Fisika Berbasis Eksperimen Virtual Terhadap Motivasi dan Hasil Belajar Fisika Siswa Kelas X MAN 2 Mataram Tahun Ajaran 2014/2015. Jurnal Pendidikan Fisika dan Teknologi. 3(1): 2407-6902.

[9] Ulya, I.F., Irawati. R., \& Maulana. (2016). Peningkatan kemampuan koneksi matematis dan motivasi belajar siswa menggunakan pendekatan kontekstual. Jurnal Pena Ilmiah. 1(1).

[10] Saragih, E.A. (2016). Pengaruh Model Pembelajaran Discovery Learning Terhadap Hasil Belajar Fisika Ditinjau Dari Motivasi Belajar Pada Materi Elastisitas dan Hukum Hooke Siswa Kelas X SMA YPPK Yos Sudarso Merauke. Jurnal Ilmu Pendidikan Indonesia. 4(1).

[11] Sudarmini, Y., Kosim., \& Hadiwijaya, A.S. (2014). Pengaruh Pembelajaran Fisika Berbasis Inkuiri Terbimbing dengan Menggunakan LKS Terhadap Kemampuan Berpikir Kritis Siswa Madrasah Aliyah Qamarul Huda Bagu Lombok Tengah. Jurnal Ilmu Pendidikan. 21(3).

[12] Mufidah, L. L. N. (2014). Brain Based Learning and Teaching. Yogyakarta: Teras.

[13] Purnama, R., Ratman., dan Solfarina. (2015). Pengaruh Mind Mapping Melalui Brain Based Learning Terhadap Hasil Belajar Siswa pada Materi Ikatan Kimia di Kelas X SMA Negeri 1 Marawola. J. Akad. Kim. 4(3): 149-154.

[14] Jensen, E. (2011). Pembelajaran Berbasis Otak Edisi Kedua. Jakarta Barat: Indeks.

[15] Diana, S., Adiesty, F., \& Mafticha E. (2017). Brain Gym (Stimulasi Perkembangan Anak Paud I). Surakarta: CV Kekata Group.

[16] Purwanto, S., Widyaswati, R., \& Nuryati. (2009). Manfaat Senam Otak (Brain Gym) dalam Mengatasi Kecemasan dan Stres Pada Anak Sekolah. Jurnal Kesehatan. 2(1): 19797621.
[17] Nahdi, D.S. (2015). Meningkatkan Kemampuan Berpikir Kritis Dan Penalaran Matematis Siswa Melalui Model Brain Based Learning. Jurnal Cakrawala Pendah. 1(1): 2442-7470.

[18] Sariana, N., Afiif, A \& Kusyairy U. (2017). Pengaruh Penerapan Brain Gym Terhadap Minat Belajar Pada Mata Pelajaran Fisika. Jurnal Pendidikan Fisika. 5(2).

[19] Hendrayana, A.S., Thaib, D., \& Rosnenty, R. (2014). Jurnal Pendidikan Terbuka dan Jarak Jauh. 15 (2).

[20] Samudera, V.M., Rokhmat, J., \& Wahyudi. (2017).Pengaruh Model Predict-ObserveExplain Terhadap Hasil Belajar Siswa Ditinjau dari Sikap Ilmiah. Jurnal Pendidikan Fisika dan Teknologi. 3(1).

[21] Facione, P. A. (2011). Critical Thinking: What It Is And Why It Counts. Insight Assessement. -: 1-28.

[22] Khuluqiyah, K., \& Arief, A. (2012). Pengaruh Penerapan Zona Alfa dengan Kegiatan Brain Gym Terhadap Hasil Belajar Siswa Pada Materi Alat-Alat Optik di Kleas VII SMP Islam Kerembung Sidoarjo. Inovasi Pendidikan Fisika, 1(1).

[23] Herliandry, L.D., Harjono. A \& 'Ardhuha, J. (2019). Kemampuan Berpikir Kritis Fisika Peserta Didik Kelas X dengan Model Brain Based Learning. Jurnal Penelitian Pendidikan IPA (JPPIPA). 5 (1):2460-2582.

[24] Nugraha. A.J., Suyitno, H., \& Susilaningsih, E. (2017). Analisis Kemampuan Berpikir Kritis Ditinjau dari Keterampilan Proses Sains dan Motivasi Belajar melalui Model PBL. Journal of Primary Education. 6(1).

[25] Medyasari, L.T., Muhtarom., \& Sugiyanti. (2017). Efektifitas Model Pembelajaran Group Investigation Berbantuan Kartu Soal Terhadap Prestasi Belajar Ditinjau dari Motivasi Belajar Pada Materi Turunan Fungsi Aljabar. Aksioma. 8(1).

[26] Amijaya, L. S., Ramdani, A., \& Merta, I. W. (2018). Pengaruh model pembelajaran inkuiri terbimbing terhadap hasil belajar dan kemampuan berpikir kritis peserta didik. Jurnal Pijar Mipa, 13(2), 94-99.

[27] Ihsan, M. S., Ramdani, A., \& Hadisaputra, S. (2019). Pengembangan E-Learning Pada Pembelajaran Kimia Untuk Meningkatkan Kemampuan Berpikir Kritis Peserta Didik. Jurnal Pijar Mipa, 14(2), 84-87.

[28] Haryati, E., Andayani, Y., \& Al Idrus, S. W. (2019). Analisis Minat Belajar Dan Kemampuan Awal Keterampilan Berpikir Kritis Siswa Pada Materi Minyak Bumi. Jurnal Pijar Mipa, 14(3), 128-134. 
J. Pijar MIPA, Vol. 16 No.1, Januari 2021: 49-56

[29] Jamaluddin, J., Jufri, A. W., Muhlis, M., \& Bachtiar, I. (2020). Pengembangan Instrumen Keterampilan Berpikir Kritis Pada Pembelajaran IPA di SMP. Jurnal Pijar Mipa, 15(1), 13-19. 